\title{
Evaluation of Traveling Parameters in Parallel Long-Distance Public Transport
}

\author{
András Lakatos ${ }^{1 *}$, Péter Mándoki ${ }^{1}$ \\ ${ }^{1}$ Department of Transport Technology and Economics, Faculty of Transportation Engineering and Vehicle Engineering, \\ Budapest University of Technology and Economics, H-1111 Budapest, Múegyetem rkp. 3., Hungary \\ * Corresponding author, e-mail: lakatos.andras@mail.bme.hu
}

Received: 23 July 2019, Accepted: 02 September 2019, Published online: 24 October 2019

\begin{abstract}
The ongoing competition between bus and railway systems in Hungarian long-distance public transport is a current problem. Long term sustainability and efficiency in passenger transport require a balanced transport policy. These subsectors need to complement each other, not compete. The parallel bus and railway links, which are present in most relations of Hungary, can result in a competition. This research analyze traveling parameters (distance and time) in case of parallel long-distance transport systems and evaluate them with a mathematical method for long term environmental and economic sustainability optimization. This investigation's hypothesis is to define difference segments of optimization gear to travel time and travel distance.
\end{abstract}

\section{Keywords}

the parallel public transport system, regression analysis, traveling parameters, long distance service

This article was originally published with an error. This version has been corrected/amended. Please see Corrigendum

(https://doi.org/10.3311/PPtr.17628)

\section{Introduction}

In Hungary, people's lives and as well as the national economy is affected by the service level of the public transport system. Therefore, development is essential for long term environmental and economic sustainability.

A parallelism exists between several settlements in Hungarian regional and long-distance public transport systems too. In this paper, authors evaluate long distance parallel public systems regarding the most important traveling parameters towards optimization.

This problem was analyzed by Farkas et al. (2010), as well as Ács (2007) and Andrejszki et al. (2014), whose investigations concern the comparative analysis of subsectors. In Europe Abramovic et al. (2017), Abramović (2018), Droździel et al. (2017), Gašparík et al. (2018), Gasparik (2018), Zitrický (2017) investigated this topic. Albert and Tóth (2008) researched this topic in a more detailed manner, arriving at an index number that is similar but based on a different approach. Zhu et al. (2012) researched the topic from the management's point of view.

Because of the complexity of the topic, this research is a piece of a multiple-detailed evaluating series.

\section{Methodology}

First, traveling relations with parallel public transport services have to be defined, which have to cover the whole of Hungary. Regarding this, 15 parallel links between Budapest and county capitals (or cities with a population of more than 20 thousand) were chosen (Fig. 1). Traveling chains were defined according to journeys from the city center to city center included accessing and egressing the bus or railway station. Regarding Fig. 1, it is possible that accessing or egressing - or both - is not required because of the geographical situation of stations.

The travel time between city $i$ and $j$ symbolizes $\left(t_{\text {traveli, }}\right)$ the total value of elapsed time with transport mode $k$. The sum of running time $\left(t_{\text {runningi, }, j}\right)$, the access time $\left(t_{\text {accessi, } j}\right)$, and the egress time $\left(t_{\text {egressi, } j}\right)$ (Eq. (1)).

$$
t_{\text {travel }, j, k}=t_{\text {runningi }, j, k}+t_{\text {accessi }, j, k}+t_{\text {egressi }, j, k}
$$

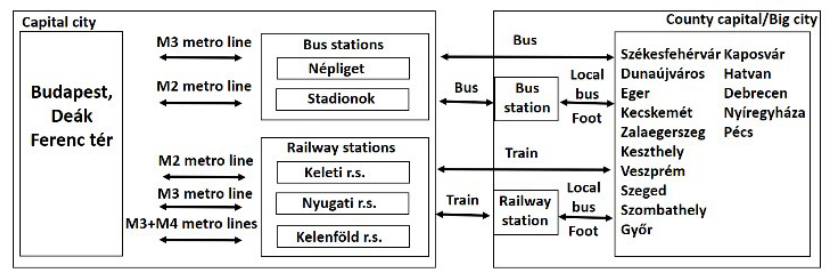

Fig. 1 Traveling chain between Budapest and county capitals/big cities (source: own source) 
Travel distance can be calculated as well as travel time Eq. (2).

$t_{\text {travel } i, j, k}=t_{\text {runningi, } j, k}+t_{\text {accessi }, j, k}+t_{\text {egressi }, j, k}$

If there are different trips in a line, the average running time and running distance values are considered. Between the starting point (Budapest, Deák Ferenc tér) and the bus stations or railway stations in Budapest, we choose the journey with the lowest value of access time. In more details:

- reaching the Nyugati railway station by metro line M3 (3 min, $1.5 \mathrm{~km}$ );

- in case of Keleti railway station by metro line M2 (5 min, $2.5 \mathrm{~km}$ );

- accessing Kelenföld railway station by metro line M3 to Kálvin tér, then metro line M4 (sum $17 \mathrm{~min}$, $5.8 \mathrm{~km}$ );

- in case of Stadion bus station by metro line M2 (7 min, $4.3 \mathrm{~km}$ );

- accessing Népliget by metro line M3 (7 min, $4.3 \mathrm{~km})$.

At bus or railway stations we added 10 minutes to access time, which covers the preparation time for the passengers (e.g. buy a ticket, reach the platform, get information, etc.).

We present theoretical, former (from before bus connections were closed) time and distance values of bus service on links that only operate railway (e.g. Budapest Győr or Budapest - Debrecen) in present days.

Each transport modes' time and distance values were compared with regression analysis appertain to Ritz methods (Péter and Szabó, 2017). Regression functions compose a linearly independent system, so none of the function can be expressed by the linear combinations of other functions. The regression functions can be trigonometrical, exponential or polynomial with exponent even or odd.

Trigonometrical functions are mainly used to describe periodical processions, so applying this type might cause serious fails because the problem is non-periodical.

In case of this examination, exponential regression functions affect them as the high value of fail as the trigonometrical.

A polynomial with even exponent is applicable for an internal interval of the evaluation, but can't describe terminal values. In contrast with this, polynomial with an odd exponent is proper for characterization of terminal sides.

Different polynomials with even exponents can be conducted by $n$ exponent function Eq. (3).

$$
f(x, \boldsymbol{a})=a_{1}+a_{2} x^{1}+a_{3} x^{2}+a_{4} x^{3}+\ldots+a_{n+1} x^{n}
$$

Variables Eq. (4)

$$
\boldsymbol{a}=\left[a_{1}, a_{2}, a_{3}, \ldots, a_{n+1}\right]
$$

are based on function system Eq. (5).

$$
\left.\begin{array}{c}
1 \cdot a_{1}+M\left[x_{i}\right] a_{2}+\ldots+M\left[x_{i}^{n}\right] a_{n+1}=M\left[y_{i}\right] \\
M\left[x_{i}\right] a_{1}+M\left[x_{i}^{2}\right] a_{2}+\ldots+M\left[x_{i}^{n+1}\right] a_{n+1}=M\left[y_{i} x_{i}\right] \\
\ldots \\
M\left[x_{i}^{n}\right] a_{1}+M\left[x_{i}^{n+1}\right] a_{2}+\ldots+M\left[x_{i}^{2 n}\right] a_{n+1}=M\left[y_{i} x_{i}^{n}\right]
\end{array}\right\}
$$

In case of linear regression (Eq. (6)) a line supremely fits to values of time and distance.

$f(x, \boldsymbol{a})=a_{1}+a_{2} x$

Vector Eq. (7)

$\boldsymbol{a}=\left[a_{1}, a_{2}\right]$

can be calculated by solving function system Eq. (8).

$\left.\begin{array}{l}M\left[\left(a_{1}+a_{2} x_{i}\right)\right]=M\left[y_{i}\right] \\ M\left[\left(a_{1}+a_{2} x_{i}\right) x_{i}\right]=M\left[y_{i} x_{i}\right]\end{array}\right\}$,

where:

$x_{i}:$ travel distance between chosen cities;

$y_{i}$ : travel time between chosen cities.

Using cubic polynomial, an Eq. (9) formed function is searched, where variables Eq. (10) can be defined based on Eq. (11).

$$
\begin{aligned}
& f(x, \boldsymbol{a})=a_{1}+a_{2} x+a_{3} x^{2}+a_{4} x^{3} \\
& \left.\begin{array}{l}
\boldsymbol{a}=\left[a_{1}, a_{2}, a_{3}, a_{4}\right] \\
M\left[\left(a_{1}+a_{2} x_{i}+a_{3} x_{i}^{2}+a_{4} x_{i}^{3}\right)\right]=M\left[y_{i}\right] \\
M\left[\left(a_{1}+a_{2} x_{i}+a_{3} x_{i}^{2}+a_{4} x_{i}^{3}\right) x_{i}\right]=M\left[y_{i} x_{i}\right] \\
M\left[\left(a_{1}+a_{2} x_{i}+a_{3} x_{i}^{2}+a_{4} x_{i}^{3}\right) x_{i}^{2}\right]=M\left[y_{i} x_{i}^{2}\right] \\
M\left[\left(a_{1}+a_{2} x_{i}+a_{3} x_{i}^{2}+a_{4} x_{i}^{3}\right) x_{i}^{3}\right]=M\left[y_{i} x_{i}^{3}\right]
\end{array}\right\}
\end{aligned}
$$

The fifth-degree regression function can be solved by Eqs. (3), (4), (5), but in this paper, we disregard the presentation of this in more details because of its complexity.

Quality of even exponent polynomials - mentioned above - can be evaluated by correlation analysis. In the course of this, the value of correlation coefficient (r) describes the connection between the variables. The more value of coefficient approximate value 1 , the better polynomial fits travel time and travel distance data. 
Based on the presented mathematical method, it is possible to evaluate the change of traveling parameters (time and distance) in case of high-speed long-distance buses which have speed limit $100 \mathrm{~km} / \mathrm{h}$ only in highways - in all relations. In this point of view, running times must be calculated based on decree regulation of rules of Hungarian road traffic (KPM-BM) No. 1/1975.

\section{Results}

Calculated values of travel time and travel distance presented in Table 1.

Based on the values of travel time and travel distance, correlation coefficients can be defined. Table 2 contains the values.

In case of bus service, cubic polynomial and fifth degree polynomial functions have the same value of correlation coefficient, linear has the lowest. It means, that cubic and fifth degree polynomials effects the lowest possible fault. In this research, cubic type was applied, because fifth degree function results unnecessary complexities in calculation.

Table 1 Calculated values of travel time and travel distance (source:

\begin{tabular}{lcccc}
\multicolumn{5}{c}{ own source) } \\
\hline Two directions & \multicolumn{2}{c}{ BUS } & \multicolumn{2}{c}{ TRAIN } \\
from/to Budapest & $s_{\text {travel }}[\mathrm{km}]$ & $t_{\text {travel }}[\mathrm{min}]$ & $s_{\text {travel }}[\mathrm{km}]$ & $t_{\text {travel }}[\mathrm{min}]$ \\
\hline Székesfehérvár & 72.9 & 95 & 70.3 & 85 \\
Dunaújváros & 79.7 & 95 & 88.3 & 148 \\
Eger & 132.6 & 127 & 144 & 151 \\
Kecskemét & 84.6 & 90 & 107.5 & 90 \\
Zalaegerszeg & 237 & 219.5 & 246.4 & 251 \\
Keszthely & 193.9 & 165 & 195.8 & 193 \\
Veszprém & 118.5 & 146 & 120.6 & 141 \\
Kaposvár & 195.6 & 175 & 209.8 & 180 \\
Hatvan & 60.7 & 77 & 69.5 & 66 \\
Debrecen & 223 & 228 & 223.6 & 173 \\
Nyíregyháza & 231 & 237 & 272 & 196 \\
Pécs & 212.8 & 268 & 230.7 & 203 \\
Szeged & 177.3 & 204 & 195.2 & 172 \\
Szombathely & 234 & 285 & 237.2 & 200 \\
Győr & 132.1 & 130 & 132.8 & 97 \\
\hline & & & &
\end{tabular}

Table 2 Values of correlation coefficient (source: own source)

\begin{tabular}{lcc}
\hline Type of function/correlation coefficient & Bus & Train \\
\hline Linear & 0.93 & 0.89 \\
Cubic polynomial & 0.94 & 0.89 \\
Fifth degree polynomial & 0.94 & 0.91 \\
\hline
\end{tabular}

Regarding Table 2, fifth degree polynomial results the lowest possible fault referring to railway service, but in case of value-section below 100 kilometers, it effects serious failures (e.g. value of travel time is zero at about 30 kilometers). Linear and cubic polynomial has the same value of correlation coefficient, so both of them fit to data pairs with the same possible fault. Because of this, linear function were used to evaluate railway service in parallel public transport system.

Regarding the chosen type of regression functions, values of travel times gear to travel distance are symbolized in Fig. 2.

Using high-speed buses in all relations, values of traveling parameters change in case of bus service. New results are contained in Table 3.

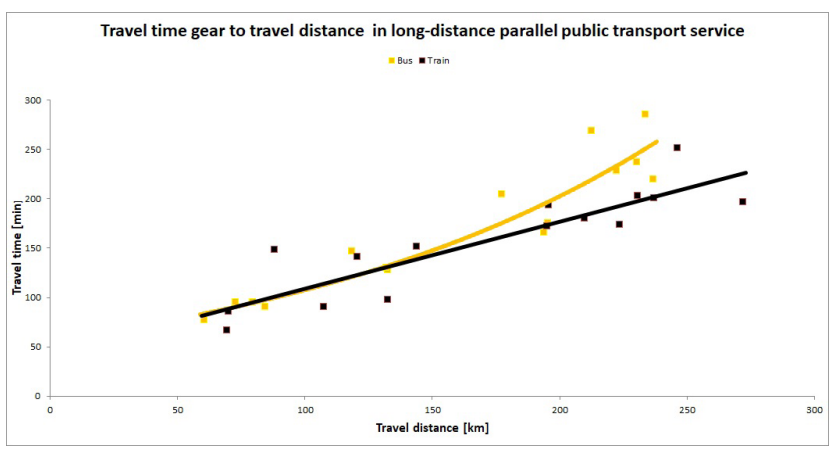

Fig. 2 Travel time gear to travel distance in long distance parallel public transport service (source: own source)

Table 3 Calculated values of travel time and travel distance using highspeed buses (source: own source)

\begin{tabular}{lcccc}
\hline Two directions & \multicolumn{2}{c}{ BUS } & \multicolumn{2}{c}{ TRAIN } \\
from/to Budapest & $s_{\text {travel }}[\mathrm{km}]$ & $t_{\text {travel }}[\mathrm{min}]$ & $s_{\text {travel }}[\mathrm{km}]$ & $t_{\text {travel }}[\mathrm{min}]$ \\
\hline Székesfehérvár & 72.9 & 78 & 70.3 & 85 \\
Dunaújváros & 79.7 & 86 & 88.3 & 148 \\
Eger & 132.6 & 127 & 144 & 151 \\
Kecskemét & 84.6 & 82 & 107.5 & 90 \\
Zalaegerszeg & 237 & 219.5 & 246.4 & 251 \\
Keszthely & 193.9 & 165 & 195.8 & 193 \\
Veszprém & 118.5 & 128 & 120.6 & 141 \\
Kaposvár & 195.6 & 175 & 209.8 & 180 \\
Hatvan & 60.7 & 67 & 69.5 & 66 \\
Debrecen & 228 & 197 & 223.6 & 173 \\
Nyíregyháza & 228.5 & 237 & 272 & 196 \\
Pécs & 218 & 225 & 230.7 & 203 \\
Szeged & 177.3 & 196 & 195.2 & 172 \\
Szombathely & 232.8 & 285 & 237.2 & 200 \\
Győr & 126.6 & 130 & 132.8 & 97 \\
\hline
\end{tabular}


Based on Table 3, values of correlation coefficients change too (Table 4), which affect the type of regression function in case of both transport modes.

Regarding bus service, values of a linear function and cubic polynomial are the same, so both of fit to calculated data. To avoid complexities of calculation, linear regression can be used.

In the case of train service, the correlation coefficient of cubic polynomial presents higher value than linear regression, which means linear type results the lowest possible fault. Value of fifth-degree polynomial is not as better as it complex.

Using the mentioned functions, results are shown in Fig. 3.

\section{Analysis and discussion}

Based on Fig. 2, the relationship between travel time and travel distance of transport modes can be divided into 3 segments presented in Fig. 4.

In the first segment, links between Budapest and cities within 150 distance, competition can be sustainable due to several reasons:

- high-speed bus service guarantees better traveling parameters by using highway than railway service. There are several city-districts, which can be reached easier by bus from Budapest (e.g. residential district in the east side of Székesfehérvár, suburban residential area in Kecskemét, garden suburb on the west side of Hatvan);

Table 4 Values of correlation coefficients in case of high-speed buses (source: own source)

\begin{tabular}{lcc}
\hline Type of function/correlation coefficient & Bus & Train \\
\hline Linear & 0.95 & 0.88 \\
Cubic polynomial & 0.95 & 0.89 \\
Fifth degree polynomial & 0.96 & 0.91 \\
\hline
\end{tabular}

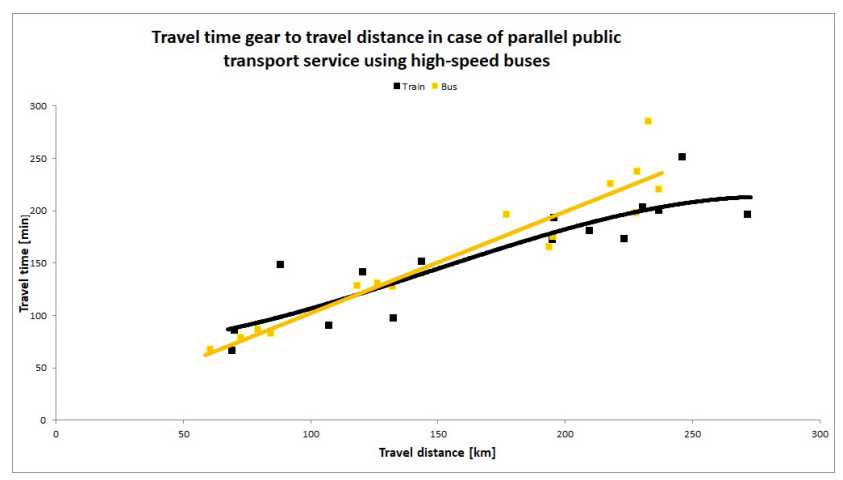

Fig. 3 Travel time gear to travel distance in case of parallel public transport service using high-speed buses (source: own source)

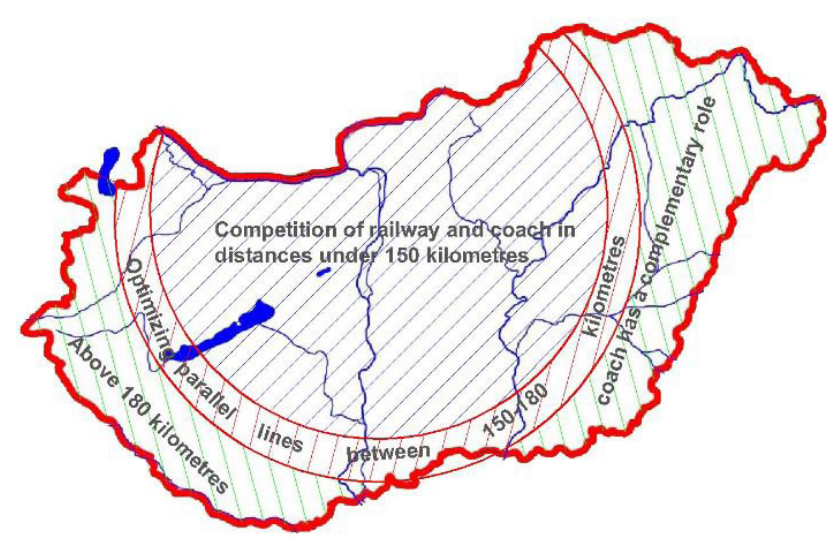

Fig. 4 Segments of optimization in case of the parallel public transport system (source: own source)

- in cities, where spatial berth of transport modes' stations are different (e.g. railway station is on the suburb and bus station is in downtown), railway service offers similar traveling parameters due to the higher value of accessing and egress time and distance (e.g. Dunaújváros);

- in cities, where public transport association does not exist, values of access and egress time are more likely high in case of using railway, because the lack of connections between railway and local lines. (e.g. Eger);

- infrastructural developments in railway lines (e.g. increasing the speed by refurbishing the line) do not achieve optimal effects (e.g. Budapest Székesfehérvár line);

- most of buses operating between Budapest and the mentioned cities using the highway with Tempo100, which means buses can run at $100 \mathrm{~km} / \mathrm{h}$ maximum speed;

- passengers do not require special preference regarding comfort within this distance (e.g. breaking stops, lavatory carriage etc.).

Based on number of passengers both transportation modes are sustainable to maintain in first section.

In the second segment, difference between railway and bus services is minimal (approximately 10 minutes) in point of travel time's view, which covers parallel links between Budapest and cities 150-180 kilometers far. In case of optimization and sustainable transport system, traffic management researches (traffic surveys, household surveys, defining the role of transport mode's links in the network, analyzing costs of operating etc.) are needed.

Parallel links between Budapest and cities above 180 kilometers from the capital city are belongs to the third section. In this case, bus services should have a complementary role to railway, because values of access and egress 
times are not so high in the traveling chain like the first and second sections, so value of travel time is not affected by access and egress time significant. It means, that railway service should guarantee better traveling parameters. Moreover, reaching city center by bus takes considerably longer in some cases (congestions, traffic signals, etc.).

Nowadays, there are several parallel lines in Hungary, which are longer than 180 kilometers (calculated from Budapest) and bus service can guarantee the same or better traveling parameters than railway service. For example trains between Budapest and Zalaegerszeg (ca. 230 kilometers) stop every small town's station, which means vehicles must stop in every 4-5 kilometers. Contrarily, highspeed buses use the highway and between Zalaegerszeg and the motorway, they stop only at main stations (e.g. Hévíz, Keszthely).

Another influential factor is the spatial situation of stations. While most of the bus stations situated in the city center, train station usually located in the outskirts of cities.

It can be stated, that railway service can prevail above 180 kilometers from Budapest in case of terms below:

- procurers (government and self-government) and providers (railway and bus companies) have to cooperate with each other to create changing points in timetables and in stations (e.g. intermodal station) too, which can guarantee the minimal value of changing time besides the higher level of comfort;

- covered - smaller towns' - train stations of each railway lines should be revised and optimized to reduce running time between Budapest and bigger cities.

Evaluating the results in Fig. 3, according to the operation of high-speed buses, the parallelism of public transport systems can be separated into 3 segments as well as above. Conclusions are the same too, but kilometer-intervals are different (Fig. 5).

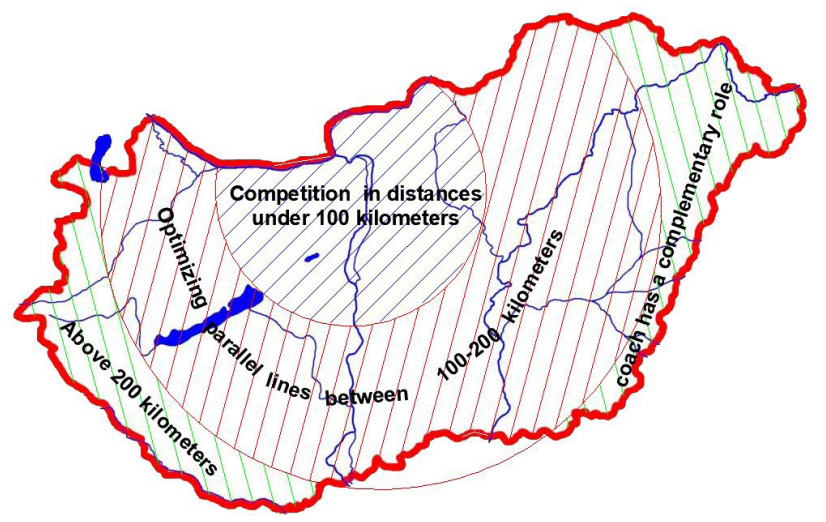

Fig. 5 Segments of optimization using high-speed buses in parallel public transport system (source: own source)
In the first segment, the border of interval changes from 150 kilometers to 100 kilometers, competition can be sustainable. Bus service guarantees better travel time values but providing enough capacity is difficult because of the volume of demand.

Second segment's borders increase from 150-180 kilometers to 100-200 kilometers, the third part of the results shows interval above 200 kilometers. Attributions of segments are the same as discussed above.

It is important to emphasize, that minimal travel time value-differences between transport modes have increased from a 30 kilometers extension zone to 100 , which means that complex traffic management researches are needed in most part of Hungarian parallel public transport system.

\section{Conclusion}

For sustainable public transportation optimization of parallel bus and railway links is needed. In Hungary, parallelism is an actual and returning problem.

It is important to evaluate parallel transport system in point of view of traveling parameters (distance, time). Passengers choose transport mode, which guarantees preferential travel time values.

In this research, we compared parallel long distance bus and railway lines between Budapest and county capitals based on the mentioned traveling parameters.

Using mathematical method regression analysis and the calculated values of travel time and travel distance, parallelism in Hungarian long-distance public transport system can be evaluated. Results show, there are 3 segments of parallelism.

In the first section (below 150 kilometers), bus and railway service guarantee the same travel time - or the difference is very low -, so maintenance parallelism in the public transport system is sustainable.

Between 150 and 180 kilometers (in the second segment), railway service offers better traveling parameters for passengers, but the difference between the examined transport modes is low (max. $10 \mathrm{~min}$ ). In this case, traffic management researches are needed to optimize parallelism.

In the third segment, above 180 kilometers from Budapest, the railway can provide significantly better values of travel time than the bus service.

Using high-speed buses results in different kilometer-intervals. The sustainable parallel public transport system should operate below 100 kilometers, traffic management researches in more details needed between 100 and 
200 kilometers, above 200 kilometers, railway guarantee preferential values of traveling parameters as it mentioned above in the third segment.

\section{References}

Abramovic, B., Zitricky, V., Mesko, P. (2017) "Draft Methodology to Specify the Railway Sections Capacity", LOGI-Scientific Journal on Transport and Logistics, 8(1), pp. 1-10. https://doi.org/10.1515/logi-2017-0001

Abramović, B. (2018) "Infrastructure Access Charges", In: Marinov, M. (ed.) Sustainable Rail Transport, Lecture Notes in Mobility, Springer, Cham, Schwitzerland, pp. 45-58. https://doi.org/10.1007/978-3-319-58643-4_4

Ács, B. (2007) "A távolsági autóbusz-hálózat múltja, jelene, jövője" (The past, present, and future of the long-distance bus network), In: KTI Évkönyv, KTI Nonprofit Kft., Budapest, Hungary, pp. 18-26. (in Hungarian)

Albert, G, Tóth, Á. (2008) "A párhuzamosság, helyettesíthetőség számszerüsítése a közforgalmú közlekedésben" (Evaluation of substitutability in the Hungarian public transport system), Közlekedéstudományi Szemle, 58(3), pp. 30-35. (in Hungarian)

Andrejszki, T., Csete, M., Török, Á. (2014) "Identifying modal shift by utility functions to reach an optimal point of regional development", In: The 14th International Conference Reliability and Statistics in Transportation and Communication (RelStat'14). Transport and Telecommunication Institute (Riga), Riga, pp. 2-8. https://doi.org/10.1515/ttj-2015-0013

Droździel, P., Rybicka, I., Madleňák, R., Andrusiuk, A., Siłuch, D. (2017) "The engine set damage assessment in the public transport vehicles", Advances in Science and Technology Research Journal, 11(1), pp. 117-127.

https://doi.org/10.12913/22998624/66502
In Hungary, there are a lot of bus lines operating above 180 kilometers, which have to be optimized.

Farkas, D., Hagymási, G., Nagy, B. (2010) "A helyközi közösségi közlekedés jelenlegi helyzetének ismertetése és hazai szervezésének lehetőségei" (Presentation of the current state of interurban community traffic and opportunities for organization in Hungary), Vezetéstudomány, 56(5), pp. 26-36. (in Hungarian)

Gašparík, J., Abramović, B., Zitrický, V. (2018) "Research on Dependences of Railway Infrastructure Capacity", Tehnički Vjesnik, 25(4), pp. 1190-1195. https://doi.org/10.17559/tv-20160917192247

Gasparik, J., Mesko, P., Zahumenska, Z. (2018) "Methodology for Tendering the Performances in Long Distance Rail Passenger Transport", Periodica Polytechnica Transportation Engineering, 47(1), pp. 19-24.

https://doi.org/10.3311/PPtr.11192

Péter, T., Szabó, K. (2017) "Combined Mathematical Modeling of Different Transport Networks, Considerations, and Complex Analysis", Acta Polytechnica Hungarica, 14(2), pp. 7-26. https://doi.org/10.12700/APH.14.2.2017.2.1

Zhu, F., Chen, S., Lv, Y., Ye, P., Xiong, G., Dong, X. (2012) "Parallel public transport system and its application in the evacuation of largescale activities" In: 2012 15th International IEEE Conference on Intelligent Transportation Systems, Anchorage, USA, pp. 102-107. https://doi.org/10.1109/ITSC.2012.6338866

Zitrický, V., Černá, L., Abramovič, B. (2017) "The Proposal for the Allocation of Capacity for International Railway Transport", In: Procedia Engineering, 192, pp. 994-999. https://doi.org/10.1016/j.proeng.2017.06.171 